\title{
Dynamic Interrelation of Cellular Ingredients Relevant to the Biosynthesis of Anthocyanin During Tissue Culture of Carrot Aggregen
}

\author{
Studies on Anthocyanins LVII*
}

\author{
by Nobuhiko SugAnO** and Kôzô HAYASHI**
}

Received August 16, 1967

\begin{abstract}
In a strain of carrot aggregen*** derived by tissue culture from cambial tissue of a red, lycopene containing carrot called "Kintoki", anthocyanin was synthesized de novo, in parallel with a simultaneous production of cinnamic acid derivatives, especially caffeic acid. On the contrary, the contents of free amino acids, malate and carotenoids were decreased down to a remarkable degree. In this case, a minor amount of auxine (IAA or 2,4-D) plays an essential role in the production of these primary as well as secondary metabolites. In these compounds, a significant difference exsists between the aggregen and genuine root in their quantity, but not in their quality, except for the production of anthocyanin. The de novo or preponderant synthesis of phenolic compound observed in this experiment must be reduced, after all, to the modification of primary metabolic pattern prevailing in the aggregen. This was discussed in relation to the biogenesis of phenolic compounds.
\end{abstract}

Recent progress in the technique of tissue culture has brought about an important development in the studies of growth and differentiation of higher plant ${ }^{1,2,3)}$. Furthermore, cultured cells or tissues in conditioned environments have also evoked a variety of important problems in the field of physiology and biochemistry of plants. Recent studies have disclosed that a considerable difference in primary and secondary metabolic patterns exists between cultured tissues and genuine ones from which they have originated ${ }^{4,5,6)}$. In particular, drastic change of secondary metabolism in cultured aggregen has been frequently observed by many workers. For instance, a marked production of anthocyanin in cultured Haplopappus cells ${ }^{7,8)}$; carotenoid formation occurring in cultured tissues of various plants ${ }^{9,10)}$; a capacity of nicotine formation acquired by tissue cultures of leaves or stems of tobacco plants ${ }^{11}$, and so on. These findings have led us to the study on the biosynthetic mechanism of secondary metabolites by the technique of tissue culture.

In the present experiment, studies on de novo synthesis of anthocyanin in carrot

* Part LVI : Proc. Japan Acad., 43, 316 (1967).

** Botanical Institute, Faculty of Science, Tokyo Kyoiku University, Ohtsuka, Tokyo, Japan.

*** The term "aggregen" is used here to denote an agglomerate of de-differentiated cells appearing in an earlier period of tissue culture. This term has also been proposed by Prof. M. Moskowitz to represent a growing, organized group of cultured mammalian cells (Nature, 203, 1233 (1964)). 
root (called "Kintoki") were planned by the use of cell aggregen derived from a tissue slice colored with anthocyanin. In the first place, metabolic background underlying in the synthesis of anthocyanin was carefully analysed in comparison with those of the genuine root tissue and its cultured aggregen which is failed to form anthocyanin under changed culture condition. In this case, some metabolites, e.g., free sugars, amino acids, malic acid, cinnamic acids and carotenoids, were carefully examined in their quality and quantity. Also, the time course in the change of these compounds was studied in relation to the biosynthesis of anthocyanin pigment.

\section{Material and Methods}

The cultured cell aggregen used in this experiment was a de-differentiated tissue obtained from fresh root of a red carrot called "Kintoki" in the following way: A small column including cambial tissue was punched out asceptically with a cork borer and cut into thinner disks. The disks were cultured on White's basal medium ${ }^{12}$ containing $1 \mathrm{ppm}$ auxine (IAA), $0.1 \%$ yeast extract and $0.8 \%$ agar. After appropriate raising of callus, ca. $250 \mathrm{mg}$ portion thereof was transplanted in a test tube $15 \times 1.8$ $\mathrm{cm}$ containing the above medium, and subcultured at $27^{\circ}$ at every four-week intervals under 5,500 lux, $12 \mathrm{hr}$ /day (Tôshiba Neoline FL $20 \mathrm{~W}$ ). Under this condition, the aggregen became deep reddish purple. This aggregen was termed AGI in the present experiment*. On the other hand, when AGI was transplanted onto the medium containing 2,4-D in place of IAA, the red color was soon degraded into brown, and finally a yellowish white aggregen was formed. This may be termed AGID. The AGID of 29-day culture and an intact "Kintoki" root were used for the comparison with the AGI of 29-day culture.

For the preparation of the starting meterial, the aggregen was collected, washed with water, blotted on a sheet of filter paper, and weighed for fresh material. This was dried in a vacuum desiccator for two days, and weighed for dry material.

Anthocyanin and anthocyanidin. The dry material of AGI was extracted twice with cold 1\% methanolic hydrochloric acid, and the combined extract was mixed with ether to precipitate the anthocyanin. An oily precipitate was dissolved in methanol, and converted into the lead salt by the addition of a methanolic solution of basic lead acetate. The bluish precipitate was collected, washed with water and methanol. From this crop, anthocyanin was recovered as chloride by treatment with $5 \%$ methanolic hydrochloric acid, and the red filtrate was evaporated to dryness in vacuo. The residual pigment was dissolved in a small volume of an upper phase of the solvent mixture, $\mathrm{BuOH} / \mathrm{AcOH} / \mathrm{H}_{2} \mathrm{O}(4: 1: 5, \mathrm{v} / \mathrm{v}$ ) (designated as $\mathrm{BAW}$ ), and the solution was passed through a column of cellulose powder (Tôyô, 200-300 mesh). The magenta and brownish zones were clearly separated one after another from the top of the column. The magenta fraction was evaporated to dryness in vacuo, and the residue was dissolved in 1\% methanolic hydrochloric acid. Then, the soultion was mixed with ether (5-6 vols.) to precipitate the pigment. A portion of the precipitate was paper-chromatographed for qualification, and another portion was hydrolyzed with $10 \%$ hydrochloric acid by heating on a boiling water bath for $15 \mathrm{~min}$. The anthocyanidin formed was transferred to iso-amyl alcohol and paper-chromatographed by the use of Forestal solvent, $\mathrm{BuOH} / \mathrm{conc}$. $\mathrm{HCl} / \mathrm{H}_{2} \mathrm{O}(7: 2: 5, \mathrm{v} / \mathrm{v})$, and phenol satu-

* This strain had already been derived in 1962 and designated as DT-3 by Dr. M. Takeuchi in the Department of Biochemistry, Saitama University. 
rated with water.

The amount of total anthocyanin was determined in the following way: The dried AGI material was powdered in a mortar, extracted with $5 \%$ hydrochloric acid and filtered. The red extract was washed successively with ether, light petroleum and benzene, and added with 5\% hydrochloric acid up to a definite volume. The total anthocyanin content was assessed in terms of $E_{\max }$ by comparison with that of cyanin solution.

Estimation of carotenoids. Fresh aggregen $(10 \mathrm{~g})$ was covered with acetone, ground in a mortar with some acid-washed quartz sand and filtered through a sintered glass filter. The acetone extract was mixed with an equal volume of ether, and water was added to this solution until two layers began to separate. An upper ethereal layer was washed with water, dried with anhydrous $\mathrm{Na}_{2} \mathrm{SO}_{4}$ and evaporated to dryness under jet stream of nitrogen. The residue was subjected to saponification as described by Goodwin ${ }^{13)}$, whereupon the whole carotenoids were taken up in light petroleum (bp. $30^{\circ}-60^{\circ}$ ). The solution was then applied to the top of active alumina column and developed with $3 \%$ acetone in light petroleum, until a deep orange zone ( $\beta$-carotene) was just passed out the column. The yellow (xanthophylls) and reddish (lycopene) zones remaining in the column were collected one by one, eluted with ether and filtered through a sintered glass filter. Each of these three fractions was evaporated to dryness under jet stream of nitrogen, and the residual pigment was identified by the characteristic VIS-absorption in each of the solvents: $n$-hexane, chloroform and carbon disulfide. Besides, the phase partition test between light petroleum and $90 \%$ methanol was also applied for this purpose. For quantitative measurement, the above pigment fractions were dissolved in a definite volume of light petroleum or hexane, and the quantity was determined on the basis of the following $\mathrm{E}_{1 \mathrm{~cm}}^{1 \%}$ values : 2500 at $449 \mathrm{~m} \mu$ for $\beta$-carotene ${ }^{14)}, 3450$ at $472.5 \mathrm{~m} \mu$ for lycopene ${ }^{15}$, and 2500 at $445 \mathrm{~m} \mu$ for xanthophylls (assumed as lutein) ${ }^{14}$.

Estimation of free or bound cinnamic acid derivatives. Dry starting meterial $(1 \mathrm{~g})$ was ground in a mortar and extracted twice with boiling $80 \%$ ethanol, each for an hour. The combined extract was filtered and evaporated to dryness in vacuo. The residue was dissolved in water, slightly acidified with hydrochloric acid and shaken with ether. The ethereal layer was extracted with $5 \% \mathrm{NaHCO}_{3}$. The bicarbonate fraction containing organic acids was treated as usual, and tested for free cinnamic acids. On the other hand, the weakly acidic aqueous layer remained above was run through a column $(1.2 \times 7.5 \mathrm{~cm} / \mathrm{g}$ dry plant material $)$ of Amberlite IR $120\left(\mathrm{H}^{+}\right.$-form), and the total effluent was evaporated to dryness in vacuo. The residue was taken up in water, and saponified with an equal volume of $4 \mathrm{~N}$ sodium hydroxide to liberate all cinnamic acids from their bound state. The reaction mixture was treated in the usual way, and the cinnamic acids obtained were separated mass-paperchromatographically on a sheet of Tôyô No. 51 filter paper using the solvent, benzene/acetic acid/water $(6: 7: 3, \mathrm{v} / \mathrm{v})$ (designated as $\mathrm{BzAW}$ ). The spots of individual acids were detected by their fluorescent colors under ultraviolet light. The bands corresponding to the individual acids were separated by cutting and eluted with ethanol. Each eluate was filled up with ethanol to a definite volume, and used for the quantitative measurement on the basis of $\mathrm{E}_{\max }\left(\lambda_{\max }: 312 \mathrm{~m} \mu\right.$ for $p$-coumaric acid, $326 \mathrm{~m} \mu$ for caffeic acid, and $324 \mathrm{~m} \mu$ for ferulic acid). Qualification of these acids was effected by careful comparison with the authentic specimens in their fluorescent colors, color reactions with sulfanilic reagent, absorption spectra, and $\mathrm{Rf}$ data obtained by the solvents, BzAW and BAW. 
Estimation of free amino acids. $5 \% \mathrm{NH}_{4} \mathrm{OH}$ and then water were run through the column same as above, and the combined eluate was evaporated to dryness in vacuo, and the residue was dissolved in a definite volume of water. This was applied on Tôyô No. 51 filter paper and developed by the two-way ascending procedure (BAW on one direction, and phenol saturated with water on the other). The chromatogram was dried in an oven, sprayed with $0.1 \%$ ninhydrine in methanol, and heated at $80^{\circ}$ for $2 \mathrm{~min}$. Each of the faintly colored spots was cut out, and put into a test tube, to which the color reagent* was added. After heating on a boiling water bath for $20 \mathrm{~min}$, the solution was quickly filtered, the tube being thoroughly washed with acetone, and filled with $0.05 \mathrm{M} \mathrm{Na}_{2} \mathrm{HPO}_{4}$ up to a definite volume. The amounts of free amino acids and amides were determined, taking an absorbance at $570 \mathrm{~m} \mu$ as a measure.

Estimation of free sugars. A definite volume of the aqueous layer containing bound cinnamic acids described above was applied on a large sheet of Tôyô No. 51 filter paper, and chromatographed by triple development with BAW. Each of the sugar zones corresponding to those of the authentic sugars developed in parallel was cut out and put into a test tube containing $3 \mathrm{ml}$ of distilled water. Elution was completed by heating on a boiling water bath for $20 \mathrm{~min}$. After filtration, $2 \%$ solution of anthrone in $\mathrm{H}_{2} \mathrm{SO}_{4}(6 \mathrm{ml})$ was added to each eluate in the cold, and the mixture was heated on a boiling water bath for $10 \mathrm{~min}$. The sugar content was determined colorimetrically based on the absorbance at $620 \mathrm{~m} \mu$.

Estimation of non-volatile organic acids. Dry material of the aggregen was extracted in the same way as described above. After evaporation of the extract in vacuo, the residue was dissolved in water, and the solution was passed through the columns of Amberlite IR 120 ( $\mathrm{H}^{+}$-form) and of formyl Dowex $1 \times 4$ (50-100 mesh), successively. All the acids retained in Dowex column were eluted with $1.5 \mathrm{~N}$ formic acid. The eluate was passed through the cation exchanger for purification and finally through anion exchanger (200-400 mesh). From the latter, organic acids were fractionated according to a gradient elution system ${ }^{16}$. For the quantitative measurement, each fraction was subjected to the titration with $0.01 \mathrm{~N} \mathrm{NaOH}$. Component analysis of individual peaks was made by paper chromatography using the solvents, $\mathrm{BuOH} /$ $\mathrm{HCOOH} / \mathrm{H}_{2} \mathrm{O}(4: 1: 2, \mathrm{v} / \mathrm{v})$ and $\mathrm{EtOH} / 28 \% \mathrm{NH}_{4} \mathrm{OH} / \mathrm{H}_{2} \mathrm{O}(16: 1: 3, \mathrm{v} / \mathrm{v})$. Bromophenol blue (BPB) was used for color development.

Spectrophotometric measurement. Quantitative determination of amino acids was made with Hitachi photoelectric photometer (Model FPW 4), and all other spectrophotometric estimations were done by means of Perkin Elmer UV spectrophotometer (Model 202).

\section{Result}

Observations on cultured aggregens. The aggregens, AGI and AGID, grew up to a constant level of weight on 29-day culture, their fresh weight being 3.7 and 4.6 times as much, respectively, in comparison with those of the original inocula. The proportion of dry weight to fresh weight was $8.5-9.0 \%$ in AGI, and 6-6.5\% in AGID, at every stage of growth. In outer appearance, AGI was relatively compact and

* Preparation of the color reagent: ninhydrine $(500 \mathrm{mg})$ and hydrindantin $(40 \mathrm{mg})$ were dissolved in ethyl cellosolve $(50 \mathrm{~m} l)$, and MacIlvaine buffer ( $\mathrm{pH} 5.4 ; 50 \mathrm{ml}$ ) was added to the solution above. 
grew up to an organized aggregen having some tracheidal cells with a spiral crest, whereas AGID was more or less crumbly and scarcely organized.

Anthocyanin and anthocyanidin. In AGI aggregen, cells containing anthocyanin are mostly located beneath the surface of aggregen or around tracheidal cells. Throughout the entire growth stage, it was found that the anthocyanin was a mixture of four components corresponding to the Rf values $0.08,0.11,0.15$ and 0.21 upon irrigation with BAW. Among these components, the last two were major ones, in which the component of Rf 0.15 did exceed another one. All these components must be the glycosides of cyanidin, since they gave rise to a single spot of cyanidin on complete hydrolysis. Moreover, the main pigment of Rf 0.15 seemed to be cyanin itself, so far as chromatographic data are concerned. At any rate, total anthocyanin content increased gradually from 7 to 29 days; that is, an increment up to $37 \%$ per gram in dry weight of aggregen cultured for 29 days (Table 3). Hence, it follows that AGI-cells continue to have an active capacity of anthocyanin formation.

Table 1. The contents of individual components found in the aggregens cultured for 29 days and in a genuine root of red carrot "Kintoki".

\begin{tabular}{|c|c|c|c|c|}
\hline \multirow{2}{*}{\multicolumn{2}{|c|}{ Components }} & \multicolumn{2}{|c|}{ Aggregens } & \multirow{3}{*}{$\begin{array}{r}\text { Root } \\
0.00\end{array}$} \\
\hline & & \multirow{2}{*}{$\begin{array}{l}\text { AGI } \\
0.70\end{array}$} & \multirow{2}{*}{$\begin{array}{r}\text { AGID } \\
0.00\end{array}$} & \\
\hline Anthocyanins ${ }^{a}$ ) & & & & \\
\hline Carotenoids ${ }^{\mathrm{b})}$ & $\left\{\begin{array}{l}\text { Xanthophyll } \\
\text { Lycopene } \\
\beta \text {-Carotene } \\
\text { Total } \\
\text { Total } *\end{array}\right.$ & $\begin{array}{r}17.40 \\
2.94 \\
5.99 \\
26.33 \\
40.15\end{array}$ & $\begin{array}{r}7.75 \\
12.97 \\
3.58 \\
24.30 \\
25.34\end{array}$ & $\begin{array}{r}30.11 \\
446.49 \\
120.58 \\
597.18 \\
646.80\end{array}$ \\
\hline Cinnamic $\operatorname{acids}^{\text {a) }}$ & $\left\{\begin{array}{l}p \text {-Coumaric acid } \\
\text { Caffeic acid } \\
\text { Ferulic acid }\end{array}\right.$ & $\begin{array}{l}0.24 \\
5.85 \\
0.48\end{array}$ & $\begin{array}{l}0.07 \\
1.58 \\
0.23\end{array}$ & $\begin{array}{r}+ \\
0.22 \\
+\end{array}$ \\
\hline Sugars ${ }^{a)}$ & $\left\{\begin{array}{l}\text { Glucose } \\
\text { Fructose } \\
\text { Sucrose }\end{array}\right.$ & $\begin{array}{r}65.88 \\
26.73 \\
+\end{array}$ & $\begin{array}{l}44.63 \\
18.75 \\
+\end{array}$ & $\begin{array}{r}55.13 \\
37.75 \\
H\end{array}$ \\
\hline & $\int_{\quad \text { (unknown) }}^{\text {Peak I }}$ & 28.30 & 26.50 & 79.80 \\
\hline Non-volatile acias & $\left\{\begin{array}{l}\text { Peak II } \\
\quad \text { (Malic acid) }\end{array}\right.$ & 32.50 & 18.50 & 391.00 \\
\hline Amino acids and amides ${ }^{\text {a) }}$ & $\left\{\begin{array}{l}\text { Leucine } \\
\text { Phenylalanine } \\
\text { Valine } \\
\text { Alanine } \\
\text { Threonine } \\
\text { Asparagine } \\
\text { Serine } \\
\text { Glutamic acid } \\
\text { Aspartic acid } \\
\text { Glutamine } \\
\text { Arginine } \\
\text { Tyrosine } \\
\text { Proline } \\
\beta \text {-Alanine }\end{array}\right.$ & $\begin{array}{l}0.58 \\
1.45 \\
0.51 \\
4.27 \\
0.26 \\
1.40 \\
1.26 \\
0.64 \\
0.40 \\
0.14 \\
\text { H } \\
- \\
-\end{array}$ & $\begin{array}{l}0.05 \\
0.20 \\
0.24 \\
0.26 \\
0.11 \\
0.10 \\
0.21 \\
0.10 \\
0.02 \\
0.09 \\
+ \\
- \\
- \\
-\end{array}$ & $\begin{array}{r}1.38 \\
4.45 \\
1.87 \\
8.34 \\
1.58 \\
10.65 \\
4.64 \\
3.23 \\
2.53 \\
5.04 \\
+1 \\
+ \\
+ \\
+\end{array}$ \\
\hline
\end{tabular}

* Calculated on the basis of $\mathrm{E}_{1 \mathrm{~cm}}^{1 \%}$ value of lutein in AGI and that of lycopene in AGID and genuine root.

a) $\mathrm{mg} / \mathrm{g}$ of dry weight.

b) $u g / g$ of dry weight.

c) micro equivalent/g of dry weight. 
Carotenoids. In general, carotenoid formation was strongly retarded in both kinds of aggregens, while in individual components no qualitative difference was observed between the aggregen and genuine root (Table 1). The red pigment appearing in intact root was obtained in a crystalline form and identified as lycopene by its characteristic absorption peaks $\left(\lambda_{\max }: 446 \mathrm{~m} \mu, 474 \mathrm{~m} \mu\right.$ and $506 \mathrm{~m} \mu$ in hexane; $480 \mathrm{~m} \mu, 507 \mathrm{~m} \mu$ and $547 \mathrm{~m} \mu$ in carbon disulfide; $458 \mathrm{~m} \mu, 485 \mathrm{~m} \mu$ and $520 \mathrm{~m} \mu$ in chloroform). As a rule, ca. $70 \%$ of the total carotenoid in a root are occupied by this pigment. In both aggregens, however, the major pigment is xanthophyll $(66 \%)$ in AGI, and lycopene (53\%) in AGID (Table 2). In other words, when the AGI is transferred to the medium containing $2,4-\mathrm{D}$, the synthesis of anthocyanin is strongly suppressed, resulting in turn in a recovery of lycopene formation as seen in a genuine root. In AGI, total carotenoid content per gram on dry weight basis reached to the maximum in 23-day culture (Table 3).

Cinnamic acids. In all aggregens three fluorescent spots have been detected

Table 2. Percentage of individual components to the total carotenoid in the aggregens and in a genuine root of red carrot "Kintoki".

\begin{tabular}{lccr} 
& \multicolumn{2}{c}{ Aggregens } & \multirow{2}{*}{ Root } \\
\cline { 2 - 3 } Carotenoids & AGI & AGID & \\
\hline Xanthophyll & 66.09 & 31.09 & 5.04 \\
Lycopene & 11.16 & 53.38 & 74.77 \\
$\beta$-Carotene & 22.75 & 14.72 & 20.19 \\
\hline
\end{tabular}

Table 3. The contents of individual components found in the aggregen AGI at its five different growth stages.

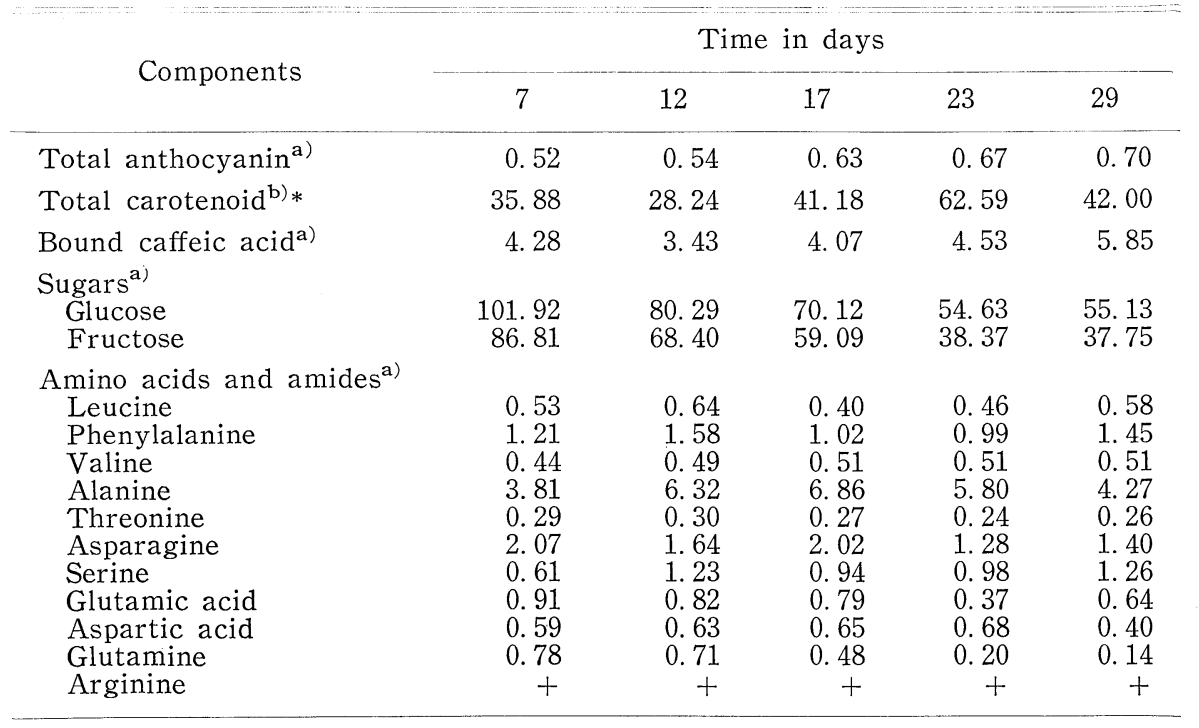

* Calculated on the basis of $\mathrm{E}_{1 \mathrm{~cm}}^{1 \%}$ value of lutein.

a) $\mathrm{mg} / \mathrm{g}$ of dry weight.

b) $u g / g$ of dry weight. 
under ultraviolet light upon exposure to fuming ammonia, and these were identified as caffeic, $p$-coumaric and ferulic acids. These acids were found mostly in ester form, and caffeic acid was a major component. Caffeic acid was most abundant in AGI, and present in lesser amount in AGID and genuine root (Table 1). Moreover, the time course studies have shown that the contents of caffeic acid and total anthocyanin per gram of dry weight were increased in parallel (Table 3).

Free sugars and amino acids. In all materials, glucose, fructose and sucrose in lesser amount were found as major components, among which glucose was preponderant. No significant difference in sugar components was observed between the aggregen and genuine root, whereas a considerable difference was found in the contents of free amino acids and amides. In general, amino acid content was much lower in the aggregens than in the root. This appeared to be affected by the kind of auxines supplemented to the medium (Table 1). As a rule, eleven kinds of amino acids and amides were found in the aggregen, while along with the same components tyrosine, $\beta$-alanine and proline were also found in a genuine root. The major components were alanine,

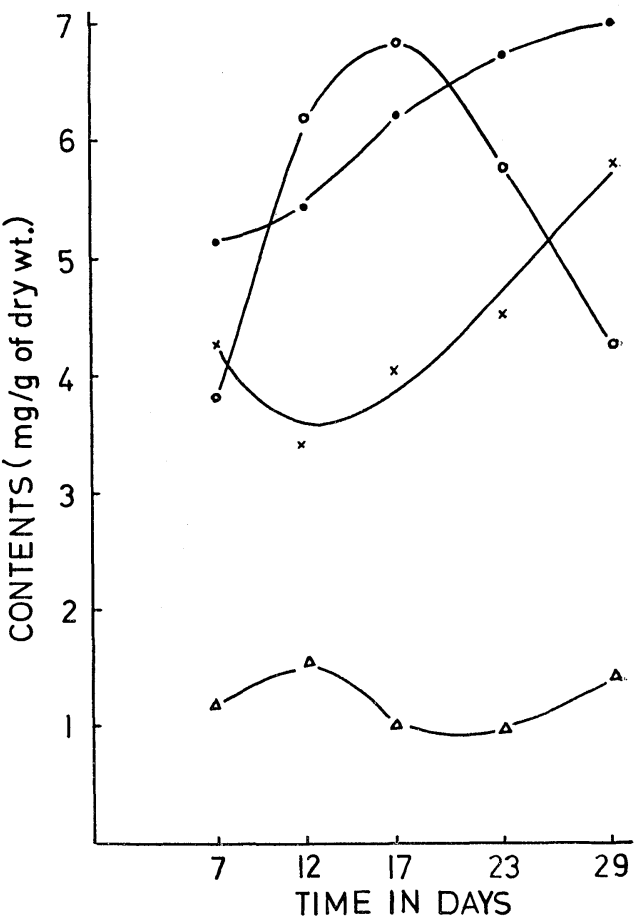

Fig. 1. Change in contents of total anthocyanin, bound caffeic acid, free alanine and phenylalanine in the aggregen AGI at five different growth stages.

- - anthocyanin ( $\times 100 \mu \mathrm{g}$ in this case),

$-x$ - bound caffeic acid,

-o- free alanine,

- $\Delta-$ free phenylalanine. phenylalanine, asparagine and serine in AGI ; alanine, valine, phenylalanine and serine in AGID; and asparagine, alanine and glutamine in the genuine root. It is particularly noteworthy that phenylalanine, a direct precursor of cinnamic acid, was found as a major amino acid common to these aggregens, and that alanine content changed to a greater extent than those of the other amino compounds, as can be seen from the time course studies (Table 1 and 3). The change reached to a maximum in 17-day culture and subsequently declined, whereas anthocyanin and caffeic acid were enhanced gradually, from 12-day culture on, up to a final level in 29-day culture (Fig. 1).

Non-volatile organic acid (Malate). As can be seen from Fig. 2, two fraction peaks were found in all materials. Among them, the substance corresponding to the peak II was determined as malate by paper-chromatographic means, while the peak I has not been identified. Thus, it is shown that malate content is larger in the aggregens than in the root (Table 1 ). 


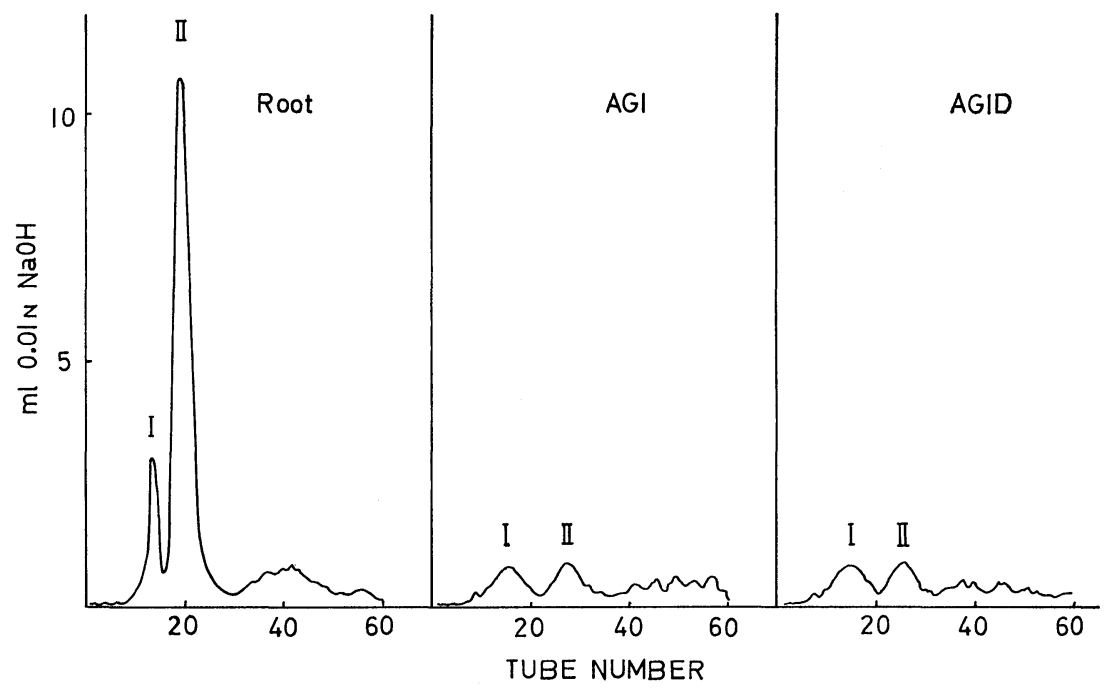

Fig. 2. Titration curves of non-volatile organic acids in the aggregens and in a genuine root of red carrot "Kintoki".

Peak I : unidentified.

Peak II: malate peak.

\section{Discussion}

The present experiments have disclosed that some drastic change occurs in primary and secondary metabolic patterns in the aggregen, and that the changed patterns are also conspicuously affected by auxines such as IAA and 2,4-D. In particular, the behavior of free amino acids, especially of alanine, and also the drastic decrease of malate and carotenoids seem to be quite significant in relation to the biogenesis of phenolic compounds.

To date, the biogenesis of aromatic compounds is known to occur at least via two synthetic pathways, namely, the acetate-malonate route and the shikimate route. On this account, it is reasonable to conceive that in the anthocyanin-producing aggregen AGI both kinks of synthetic pathways must have been established under the environment appropriately conditioned for tissue culture. In view of the outstanding behavior of alanine observed in this experiment, a problem arises whether or not this substance is utilized as one of the precursors of phosphoenolpyruvic acid (PEP), since the latter has been shown to be a starting material on the shikimate pathway. If this is true, alanine must get into the biosynthetic pathway after conversion into pyruvic acid by transamination. In this connection, several authors ${ }^{17,18)}$ have already described on an availability of pyruvic acid for the biosynthesis of phenolic compounds, and others ${ }^{19,20)}$ have also made some serious discussions in the same direction. Now that an introduction of pyruvic acid into the shikimate pathway becomes quite plausible, alanine may well participate in the biosynthesis of phenolic compounds.

However, a conspicuous increase of phenolic compounds in the aggregen cannot be satisfactorily explained merely by the participation of alanine. Especially, the fact, that not only free amino acids except alanine but also malate and carotenoid are much less enhanced in the aggregen than in a genuine root, may also indicate 
some modification of respiratory mechanism prevailing in the aggregen grown under special conditions. On this account, it seems of special interest that a new and promotive synthesis of phenolic compounds is to be discussed in detail in connection with the mechanism of respiration. In general, two respiratory pathways have been known to proceed in higher plants, i.e., the Embden-Meyerhof-Parnas (EMP) pathway and the pentose phosphate (PP) pathway. By their extensive experiments on various plants including carrot, Beevers and $\mathrm{Gibbs}^{21}$ have reported that the PPpathway plays a preferential role in plant respiration. Moreover, attractive experiments have also been reported on the action of auxines ${ }^{22,23)}$ in connection with glucose dissimilation. Besides, a recent paper has reported that the PP-pathway seems to play an important role in the respiration of certain de-differentiated tissue (callus or out-growth) ${ }^{24)}$. Considered from the result of the present experiments, glucose dissimilation in the aggregen is likely to proceed along the PP-pathway rather than the EMP-pathway, whereby an enhanced production of phenolic compounds would be well explained, since the PP-pathway involves erythrose 4-phosphate as an intermediate, which is known to be another starting material on the shikimate pathway.

Moreover, a conspicuous decrease of carotenoid content in the aggregen seems to indicate that the turnover of acetyl CoA into secondary metabolites has undergone a considerable modification. A similar result in malate content suggests that malate lingering in a storage pool also enters a turnover pool ${ }^{25}$, and/or that the native respiratory pathway, e.g., TCA cycle, has appreciably modified. At any rate, the present experiment shows that in the aggregen the mechanism of conversion is considerably different from that in an intact plant. In what manner and ways does metabolic alteration lead to an enhancement of phenolic compounds? The question is quite provocative, yet remains still to be answered.

Among other things, special interest of the present writers lies in that the aggregen AGI has the synthetic capacity of both anthocyanins and cinnamic acid derivatives, while the AGID is completely devoid of the former. This may indicate that 2,4-D acts as an inhibitor for the acetate-malonate pathway itself or some other related functions. Still, it is difficult to discuss here on a mode of action of auxine in relation to the biosynthesis of phenolic compounds.

\section{Acknowledgement}

The authors wish to express their cordial thanks to Dr. M. Takeuchi of Saitama University and Dr. K. Soma of Tokyo Kyoiku University for their valuable suggestions during the course of this work.

This work was supported by the fund from the Ministry of Education.

\section{References}

1) Steward, F. C., Blakely, L. M., Kent, A. E., and Mapes, M. O., Brookhaven Symp., No. 16, 73 (1963).

2) Steward, F.C., Plant Tissue and Organ Culture, Symp., 178 (Maheshwari, P. and Rangaswamy, N.S., Ed., Catholic Press Co., Ranchi, India, 1963).

3) Kato, H., and Takeuchi, M., Plant and Cell
Physiol. 4 : 243 (1963).

4) Weinstein, L. H., Nickell, L. G., Laurencot, H. J., Jr., and Tulecke, W., Contrib. Boyce Thompson Inst. 20 : 239 (1959).

5) Tulecke, W., Weinstein, L. H., Rutner, A., and Laurencot, H. J., Jr., ibid. 21: 291 (1962).

6) Weinstein, L.H., Tulecke, W., Nickell, 
L. G., and Laurencot, H.J., Jr., ibid. 21 : 371 (1962).

7) Steward, F. C., Blakely, L. M., Amer. Jour. Bot. 51: 809 (1964).

8) Ardenne, R., Z. Naturforschg. 20b: 186 (1965).

9) Goodwin, T.W., Chemistry and Biochemistry of Plant Pigment, 138 (Goodwin, T.W., Ed., Academic Press Inc., New York, 1965).

10) Williams, B. L., and Goodwin, T.W., Phytochemistry 4:81 (1965).

11) Scott, T.A., and Hussey, H., Nature 201 : 614 (1964).

12) White, P.R., The Cultivation of Animal and Plant Cells, p. 60 (2nd ed., Ronald Press Co., New York, 1963).

13) Goodwin, T.W., Modern Methods of Plant Analysis 3: 281 (Paech, K., and Tracey, M. V., Ed., Springer, Heidelberg, 1955).

14) Goodwin, T.W., Biochem. J. 68: 503 (1958).

15) Davies, B.H., Chemistry and Biochemistry of Plant Pigments, 530 (Goodwin, T. W., Ed., Academic Press Inc., New
York, 1965).

16) Palmer, J.K., and Wyman, A. H., Phytochemistry 4 : 305. (1965).

17) Coscia, C. J., Ramirez, M. I., Schubert, W. J., and Nord, F. F., Biochemistry 1: 447 (1962).

18) Yoshida, S., and Towers, G. H. N., Can. Jour. Biochem. Physiol. 41 : 579 (1963).

19) Brown, S. A., Biochemistry of Phenolic Compounds, 366 (Harborne, J. B., Ed., Academic Press Inc., New York, 1964).

20) —, Ann. Rev. Plant Physiol. 17 : 223 (1966).

21) Beevers, H., and Gibbs, M., Plant Physiol. 29 : 322 (1954).

22) Gibbs, M., and Beevers, H., Plant Physiol. $30: 343$ (1955).

23) Humphreys, T.E., and Dugger, W. M., Jr., Plant Physiol. 34: 112 (1959).

24) Morohasni, Y., Komamine, A., Satô, M., and Shimokoriyama, M., Bot. Mag. Tokyo 78 : 43 (1965).

25) Ranson, S. L., Plant Biochemistry, 518 (Bonner, J., and Varner, J.E., Ed., Academic Press Inc., 1965).

菅野延彦・林 孝三：ニンジンの培養細胞集塊 (Cell aggregen)

におけるアントシアニンおよび桂皮酸類の生成について.

赤色系ニンジン「金時」の根をホワイト基本培地，酵母抽出物，IAA 含む寒天培地上で䖝光灯照射下 で培養すると，アントシアニン，およびカフェ酸を主体とする桂皮酸類を大量に生成する細胞集塊 (AGI) が分離する、さらに，こ我をIAA の代りに 2,4-D を含む培地に移植すると、アントシアニンをほとえど 生産しない白黄色の細胞集塊 (AGID) が得られる。こ机ら AGI, AGID ではもとの根の組織に比べ, とも に遊離了ミノ酸, リンゴ酸, カロチノイドの各量が著るしく低下している。したがって, AGI にみら机る ようなフェノール性化合物の生産性は, オーキシンを主体とする培養条件下における一次代謝型の变動にも とづくものと思わ机る.とくに，AGI に抢ける遊離アラニン量の経時テストによって示された交動は，こ れらフェノール性化合物生成系との関連において注目される。したがって, アラニンのシキミ酸経路への転 換もしくはこの経路を支える呼吸系と, AGI におけるフェノール性化合物生成系の台頭との関係が論義さ 机た。(東京教育大学理学部植物学教室) 